University of Nebraska - Lincoln

DigitalCommons@University of Nebraska - Lincoln

Uniformed Services University of the Health

Sciences

U.S. Department of Defense

2011

Startle response related genes

Lei Zhang

Uniformed Services University of the Health Sciences, Lezhang@USUHS.mil

Xian-Zhang Hu

Uniformed Services University of the Health Sciences

$\mathrm{He} \mathrm{Li}$

Uniformed Services University of the Health Sciences

Xiaoxia Li

Uniformed Services University of the Health Sciences

Stanley Smerin

Uniformed Services University of the Health Sciences

See next page for additional authors

Follow this and additional works at: https://digitalcommons.unl.edu/usuhs

Part of the Medicine and Health Sciences Commons

Zhang, Lei; Hu, Xian-Zhang; Li, He; Li, Xiaoxia; Smerin, Stanley; Benedek, David M.; and Ursano, Robert, "Startle response related genes" (2011). Uniformed Services University of the Health Sciences. 74. https://digitalcommons.unl.edu/usuhs/74

This Article is brought to you for free and open access by the U.S. Department of Defense at DigitalCommons@University of Nebraska - Lincoln. It has been accepted for inclusion in Uniformed Services University of the Health Sciences by an authorized administrator of DigitalCommons@University of Nebraska Lincoln. 


\section{Authors}

Lei Zhang, Xian-Zhang Hu, He Li, Xiaoxia Li, Stanley Smerin, David M. Benedek, and Robert Ursano 


\title{
Startle response related genes
}

\author{
Lei Zhang*, Xian-Zhang Hu, He Li, Xiaoxia Li, Stanley Smerin, David M. Benedek, Robert Ursano \\ Center for the Study of Traumatic Stress, Department of Psychiatry, Uniformed Services, University of the Health Sciences, Bethesda, MD 20814, United States
}

\section{A R T I C L E I N F O}

\section{Article history:}

Received 29 April 2011

Accepted 7 July 2011

\begin{abstract}
A B S T R A C T
The startle reaction (also known as the startle response, the startle reflex, or the alarm reaction) is the psychological and physiological response to a sudden unexpected stimulus, such as a flash of light, a loud noise (acoustic startle reflex), or a quick movement near the face. Abnormalities of startle response have been observed in many stress-related mental disorders, such as schizophrenia and post-traumatic stress disorder (PTSD). However, the molecular mechanisms of startle in stress-associated conditions - for example, whether the startle reaction is associated with any gene variance - is still unknown. In this paper, we will carry out a systematic review by retrieving, assessing, and combining, when applicable, individual studies investigating association of the molecular variation of candidate gene with the startle response. The systematic review is based on the search for numerous publications using the keywords "startle gene" on September 15, 2010 using PubMed, which comprises more than 20 million citations for biomedical literature from MEDLINE and life science journals. A total of 486 publications regarding genes associated with startle have been obtained and reviewed here. There are fewer than 20 publications associating genes with the startle response between 1979, when the first valuable paper was published, and 1999. However, publications have dramatically increase from 2001 and reaches over 70 in 2009. We have characterized them into three categories: startle-associated gene studies in humans, in animals, as well as in both human and animals. This review of research strategy may provide the information for identifying a biomarker for startle response, with the objective of translating research into clinical utility: diagnosis and treatment of stress-induced mental disorders.
\end{abstract}

Published by Elsevier Ltd.

\section{Introduction}

An exaggerated startle response, considered as a critical characteristic in certain mental disorders, such as PTSD and schizophrenia, has been avidly studied in psychiatry. Research seeking the molecular mechanism of the startle response has consistently increased over last 10 years. One such area of research is the study of genes associated with the startle response. The published articles about startle response associated genes have been significantly increased yearly. As a phenotype, the startle response exhibits a consistent physiological pattern including physical movement away from a given stimulus, a contraction of the muscles of the arms and legs, blinking, and changes of blood pressure, respiration, and breathing rate. The muscle reactions generally resolve themselves in a matter of seconds, while other responses may take longer. The pathway for this response was largely elucidated in rats in the 1980s [1].

The basic neuroanatomy, which is demonstrated by experiments with rats using a variety of lesion and electrical stimulation procedures, is relatively simple for startle responses. The signals

\footnotetext{
* Corresponding author. Tel.: +1 301295 0921; fax: +1 3012950923.

E-mail address: Lezhang@USUHS.mil (L. Zhang).
}

are conducted to the central nervous system. The output end of the startle circuitry goes through the reticulospinal tract and the lower motor neurons of the spinal cord. For example, the pathway for acoustic startle is from the ear up to the nucleus of the lateral lemniscus (LLN) from where it then activates a motor center in the reticular formation. LLN sends descending projections to lower motor neurons of the limbs. The whole reflex takes place in less than $10 \mathrm{~ms}$ [2]. Accordingly, the human startle response can be measured reliably. For example, it can be measured by the amplitude of eye blinking in response to a sudden abrupt auditory stimulus [3]. Besides the above control circuitry, the startle circuit is regulated by several brain regions, such as the prefrontal cortex and amygdala, which influence the tone of startle and the processing of information related to conditional fear [4], respectively.

There are two typical examples for regulation of the startle response. First, is prepulse inhibition (PPI). PPI is a neurological phenomenon in which a weaker pre-stimulus (prepulse) inhibits the reaction of an organism to a subsequent strong startling stimulus (pulse) [5]. The reduction of the amplitude of startle reflects that the nervous system temporarily adapts to a strong sensory stimulus when a preceding weaker warning signal is given. PPI deficits are noted in patients with schizophrenia [6-9] and Alzheimer's disease, and in people under the influence of drugs, surgical manipulations, or gene mutations. 
The second example for regulation of the startle response is startle habituation. Startle response can be decremented by repeated presentation of the same, initially novel stimulus [10]. This regulatory mechanism can be inhibited. Schizophrenia patients exhibit impairment of startle habituation. In general, exaggerated startle reactivity can become a chronic condition to lasting for 30,40 , or more years [11].

If human behavioral traits result from the interplay of genes and environment, exaggerated startle response may have a complex genetic basis. Although it is not necessarily inherited in strict Mendelian fashion, the transmission of hereditary characteristics does pass from parents to offspring. Factors such as incomplete penetrance - (carriers of the disease allele not becoming ill or having a later onset), pleiotropy (multiple effects of a single gene), heterogeneity (similar phenotype from different genotypes), epistasis (interaction of multiple alleles in the same subject) and epigenetics among others, must be accounted for. Since startle is a peculiar behavioral response to stimuli, it represents an excellent model for studying the mechanism of interaction of gene and environment. We hypothesize that startle is an endophenotype (a concept which divides behavioral symptoms into stable phenotypes with a clear genetic connection - seen in mental disorders, such as schizophrenia and PTSD). It is possible to identify a gene, which is associated with startle response in a specific environment, for example, in subjects who experiences the Iraq war and in a restrictive population, such as military subjects. Those environmental factors, such as war exposure and subjects, can be defined. The determination of which genes are associated with startle response is a challenge.

There are 486 publications regarding gene and startle response. Fewer than 20 of these were published between 1979 and 1999. The total numbers of publications have increased markedly since 2001, reaching over 70 publications in 2009. Depending on the research subjects, they can be categorized into: studies in human subjects (Table 1), studies in animals (Table 2) and studies in both human and animals. There are 13 genes which are associated with startle response in human studies. Four genes have been studied in both human and animals, including COMT, GLRA1, GlyT2, and NRG1 dehydrogenase. Here we briefly discuss several genes which are associated with startle response in both humans and animals, and in psychiatric researches.

\section{The 5-HT transporter (5-HTT) and startle response}

There are studies regarding 5-HTTLPR (serotonin-transporterlinked promoter region) and startle-related topics. 5-HTTLPR is a degenerate repeat polymorphic region in SLC6A4, the gene that codes for the serotonin transporter $[30,31]$ and is associated with many neuropsychiatric disorders [32]. The 5-HT transporter (5HTT) influences on neural circuits processing fear and anxiety are discussed [33]. 5-HTTLPR, a functional polymorphism of the 5'flanking region of the 5-HTT gene is involved in several neuropsychiatric phenotypes [34]). 5-HTTLPR is an insertion/deletion polymorphism with a long (L) variant comprising 16 copies of a 20 $23 \mathrm{bp}$ repeat sequence and a short (S) variant comprising 14 copies. Among Caucasians, the frequencies of the $\mathrm{L}$ and $\mathrm{S}$ alleles are about 0.60 , and 0.40 , respectively [35]. An association study regarding 5HTT, especially the $S$ allele with anxiety, fear and startle response has been studied in human subjects (Table 1). The $\mathrm{S}$ allele is associated not only with increased scores in measures of negative emotionality including anxiety [36-38], but also with lower transcriptional efficiency of the 5-HTT gene and lower levels of 5-HT uptake [30,35]. S allele carriers show stronger amygdala activity in response to fear stimuli than L/L homozygotes [33] and increased anxiety $[39,40]$. The $S$ allele is also specifically associated with stronger overall startle responses than L/L homozygotes [41]. S allele carriers were not only more sensitive to the effects of stressful life events than L/L homozygotes, but also were more likely to develop depressive symptoms [42-47]. S allele carriers with low social support had an increased risk for behavioral inhibition, indicating that in the early years of life before maturation of prefrontal regulatory circuits, stress could produce stronger response to fearful stimuli. In addition, stressful life events may have cumulative effects $[42,45]$. However, there is a negative result in the study of the relation of 5-HTTLPR with fear and anxiety [45]. No interaction of 5-HTTLPR and stressful life events was found on the risk for generalized anxiety disorder in adults, although the positive results demonstrated an interaction of 5-HTTLPR and environment on fear and anxiety in children.

\section{COMT genetic variation and startle response}

One of the promising, well-studied candidates for the association of gene with startle is the gene for catechol-O-methyltransferase (COMT), the catabolic enzyme for dopamine, norepinephrine, and epinephrine. COMT is the major clearing step for dopamine in the prefrontal cortex $[48,49]$ and expressed in many brain regions synaptically [50,51] and subcortically [52]. The COMT gene contains a common functional polymorphism resulting from a non synonymous $G$ to $A$ base pair substitution in the coding sequence of the gene, producing a valine to methionine substitution at position 158 of the membrane bound allozyme that predominates in the brain (MB-COMT); soluble allozyme S-COMT [53]. Since the

Table 1

Startle associated gene studies in human subjects.

\begin{tabular}{|c|c|c|c|c|}
\hline Gene & Location & Polymorphism & Phenotype & References \\
\hline \multirow[t]{2}{*}{ 5-HT(2A)R } & 13q14-q21 & A-1438 G and T102C & PPI & {$[12,13]$} \\
\hline & & $\mathrm{T} 102 \mathrm{C}$ & PPI & [14] \\
\hline AVPR1a & $12 q 14-15$ & VNTR (RS1 and RS3) & PPI & [15] \\
\hline \multirow[t]{2}{*}{ AADC } & $7 p 12.2$ & $1303 \mathrm{C}>\mathrm{T}$ & Startle & {$[16,17]$} \\
\hline & & 1367ins A & & \\
\hline COMT $^{*}$ & 22q11.21 & Val158Met & PPI & [18] \\
\hline CSF1-R ${ }^{*}$ & $5 q 32$ & D5S209, and D5S119 & Hyperekplexia & {$[19,20]$} \\
\hline DRD3 & 3q13.3 & Ser9Gly & PPI & [21] \\
\hline DRD4 & $11 \mathrm{p} 15.5$ & 7-folds repeat & Startle & [22] \\
\hline GLRA1* & $5 q 32$ & Arginine271proline & Hyperekplexia & [23] \\
\hline \multirow[t]{2}{*}{ GlyT2* $^{*}$} & $11 \mathrm{p} 15.1$ & Arg271Pro & Hyperekplexia & [20] \\
\hline & & 910A $>$ C/Lys304Gln & Hyperekplexia & [24] \\
\hline HTTLPR & $17 q 11.2$ & $\mathrm{~S} / \mathrm{L}$ & Startle & {$[25,26]$} \\
\hline NRG1* & $8 p 12$ & rs3924999/rs10503929 & PPI & [27] \\
\hline PRODH & $22 q 11.21$ & $1945 \mathrm{~T} / \mathrm{C}, 1766 \mathrm{~A} / \mathrm{G}, 1852 \mathrm{G} / \mathrm{A}$ & PPI & [28] \\
\hline TPH2 & 11p15.3-p14 & $-703 \mathrm{G} / \mathrm{T}$ & Startle & [29] \\
\hline
\end{tabular}

* Study in both human and animals. COMT, catechol-O-methyl-transferase; HTTLPR, serotonin-transporter-linked promoter region; TPH2, tryptophan hydroxylase 2 . 
Table 2

Startle associated gene studies in animals.

\begin{tabular}{|c|c|c|c|}
\hline Gene & Phenotype & Species & References \\
\hline 5-HT(1A) receptor & PPI/Acoustic startle & Rats & {$[88]$} \\
\hline 5-HT(1B) receptor & PPI/Acoustic startle & KO mice & [89] \\
\hline COMT $^{*}$ & PPI & Transgenic mice & [90] \\
\hline D1/D2 & Startle/PPI & Rats & {$[91,92]$} \\
\hline FGFR-3 & PPI/Acoustic startle & Fgfr $3^{-1-}$ null mutant mice & [93] \\
\hline Glr-1 & Startle & Spasmodic recessive mouse & [94] \\
\hline GLP-1 & Startle & KO mice & [95] \\
\hline GLRA1* & Startle & Mutant mice & [96-99] \\
\hline GlyT2* & Hyperekplexia & GlyT2 deficient mice & {$[100]$} \\
\hline Histamine $\mathrm{H} 1$ & PPI & KO mice & [101] \\
\hline Huntington's disease gene & PPI & Transgenic mice & [102] \\
\hline mGluR5 & PPI & KO mice & [103] \\
\hline Nicotinic receptors with beta3 subunit & PPI & Mice with null mutation & [104] \\
\hline NMDA receptor & PPI/Acoustic startle & Rearing rat in isolation & [105] \\
\hline NRG1* & PPI & $\mathrm{NRG} 1^{+1-}$ mice & [106] \\
\hline \multirow[t]{2}{*}{ NPY } & Acoustic startle/PPI & KO mice & {$[107,108]$} \\
\hline & PPI & Male Wistar rat-pups & \\
\hline Oxytocin (Oxt) & PPI & Oxt KO mice & [109] \\
\hline
\end{tabular}

* Animal + Human study

158Met form is less thermo-stable than the Val158 form, it has lower activity at physiologically relevant temperatures in the brain [54]. Met158 homozygotes have an approximate one-third diminution in activity compared with Val158 homozygotes [55]. Lowered COMT activity, resulting in higher concentrations of dopamine [49], may have a salutary effect on cortical function. For instance, the Val158 (higher activity) allele is associated with prefrontal inefficiency during working memory and cognitive control [56-59], with relatively poorer performance on prefrontally mediated tasks [60-62]. Furthermore, the Val158 allele is associated with schizophrenia - particularly in interaction with other schizophrenia risk genes [53,63]. However, as both alleles are maintained at high levels in populations worldwide, it has been proposed that each confers an environment-specific selective advantage - representing a trade-off between cognitive efficiency and emotional resiliency [64]. The Met158 allele is linked to poor emotion regulation, anxiety disorders [65-70], anxietyrelated traits including high neuroticism and low sensation seeking and extraversion [71-74], obsessive-compulsive disorder [75], and increased pain sensitivity [76]. However, the results of such associations are not entirely consistent.

COMT Val158Met genotype affects functional activation and connectivity within critical neural circuits for affective arousal and regulation. Smolka et al. [77] found that the Met158 allele was associated in an allele dose-dependent manner with exaggerated limbic and prefrontal engagement in response to aversively valenced pictures. An additive interaction was also found between genotypes at the COMT Val158Met locus [78]. The Met158 allele is also associated with increased hippocampal and ventrolateral prefrontal activation while viewing angry and fearful facial expressions; these brain regions showed augmented functional connectivity in Met158 homozygotes, the magnitude of which negatively predicted scores on a temperamental measure of flexibility [79]. Study of COMT in relation to the startle response demonstrated that COMT genotype significantly affected startle reflex modulation by aversive stimuli. Met158 homozygotes show a markedly potentiated startle reflex compared with Val158 carriers. A trait measure of anxiety [80] was also associated with acoustic affective startle reflex modulation.

\section{Glycine receptor subunit alpha 1(GLRA1) mutation associated with startle response in an atypical hyperekplexia?}

Individuals with hyperekplexia have an excessive startle reaction to sudden unexpected noise, movement, or touch, suggesting defects in glycinergic neurotransmission. A GLRA1 mutation associated with startle response was discovered in subjects with hyperekplexia, a rare neurological disorder characterized by an exaggerated startle response, infantile hypertonia and hyperreflexia without spasticity, a hesitant gait that usually improves by 3 years of age, and nocturnal myoclonus. Familial hyperekplexia is usually autosomal dominant, with the mutated inhibitory GLRA1 gene being on chromosome $5 \mathrm{q}$. Three generations of a family have been identified with progressively more severe phenotypes of hyperekplexia. All affected family members were found to be heterozygous for a novel arginine 271 proline mutation in GLRA1. Affected members of the third generation, now aged 6 and 7 years, exhibited enhanced startle responses [26].

Within the hyperekplexia, there are two clinical forms. The major form exhibits continuous generalized stiffness in the first year of life and an exaggerated startle reflex, accompanied by temporary generalized stiffness and falls, whereas the minor form only shows excessive startle and hypnic jerks. The GLRA1 mutations are responsible for the major form of hyperekplexia. However, genetic analysis of the GLRA1 gene of two English families in which both forms of hyperekplexia were present revealed no genetic defect in the GLRA1 gene [81].

More recently, missense, nonsense and frame-shift mutations have also been identified in the glycine transporter GlyT2 gene, SLC6A5, demonstrating a presynaptic component to this disease. Further mutations, albeit rare, have been identified in the genes encoding the GlyR $\beta$ subunit (GLRB), collybistin (ARHGEF9) and gephyrin (GPHN) - all of which are postsynaptic proteins involved in orchestrating glycinergic neurotransmission. Whether these genes are also associated with exaggerated startle response in stress-related disorders is still unknown.

\section{Is p11 (S100A10) associated with startle response?}

Previous studies have reported that $\mathrm{p} 11$ is associated with both depression [82] and PTSD [83,84]. P11 mRNA was down-regulated in the brain of patients with depression, but up-regulated in the brain of those with PTSD. P11 is a member of the S100 family of proteins containing two DF-hand calcium-binding motifs, which are localized in the cytoplasm and/or nucleus in a wide range of cells [85]. P11 regulates a number of cellular processes such as cell cycle progression and differentiation, is implicated in exocytosis and endocytosis by reorganization of F-actin, and interacts with and transports the 5-HT1B receptor from the cytoplasm to the membrane [82]. This suggests that p11's regulation of the 5-HT1B 
receptor is critical to mental status. P11 knock-out mice showed behavioral changes similar to depression. Because of dysregulation of 5-HT1B receptor trafficking, p11 knock-out mice respond more poorly to antidepressant medication than did wild type [82]. Antidepressant medication increased expression levels of p11 and reversed the depressive behavior [82]. A recent study demonstrated that p11 mRNA expression levels are lower in the stress-related brain regions of suicide subjects $[86,87]$. Peripheral blood mononucleocyte p11 mRNA levels were significantly lower in suicide attempters and higher in suicide non-attempters, when compared to normal controls [87]. This data suggest that p11 mRNA levels may be a potential adjunctive biomarker for the assessment of suicide risk in mental disorders. However, there is a study demonstrating no association of $\mathrm{p} 11$ polymorphism with major depression. Therefore, it would be worthwhile to examine the influence of the p11 polymorphism and the role of $\mathrm{p} 11$ on the overall startle response.

\section{BDNF and startle}

Brain-derived neurotrophic factor, also known as BDNF, is a member of the "neurotrophin" family of growth factors, which are related to the canonical "Nerve Growth Factor", NGF. Neurotrophic factors are found in the brain and the periphery [110]. The BDNF gene is located on chromosome 11 [111,112]. BDNF protein is synthesized as a glycosylated precursor (proBDNF) and is then converted intracellulary to mature BDNF protein, which is released upon cell stimulation [113]. Several studies demonstrated that BDNF is associated with depression [110-112,114].

Exposure to stress and the stress hormone corticosterone has been shown to decrease the expression of BDNF in rats [115]. In addition, rats bred to be heterozygous for BDNF, therefore reducing its expression, have been observed to exhibit hippocampal atrophy, suggesting that an etiological link exists between the development of depression and BDNF. Supporting this link, the excitatory neurotransmitter glutamate, voluntary exercise [116], caloric restriction, intellectual stimulation, curcumin [117], antidepressants [118], electroconvulsive therapy [119], and sleep deprivation [120] increase expression of BDNF in the brain. Some of these treatments, such as drugs and electroconvulsive therapy [121], have been shown to protect or reverse hippocampal atrophy, which is seen in PTSD.

Although the results are not always in the same direction, a common single-nucleotide polymorphism in the BDNF gene - a methionine (Met) substitution for valine (Val) at codon 66 (Val66Met) - is associated with alterations in brain anatomy and memory. Positive associations of the BDNF Val66Met have been reported with specific symptoms of depressive disorders [122]. Egan and co-workers found a functional relevance of this substitution and of the lower activity-dependent secretion of BDNF which is associated with the Met allele as compared to the Val allele $[123,124]$. There is an effect of genotype on memory and cognitive performances [123] and an effect of the Val66Met polymorphism of BDNF gene on brain morphology, with Met carriers having a reduced volume of different brain structures, including hippocampus, parahippocampal gyrus and prefrontal cortex $[125,126]$.

A variant BDNF mouse (BDNFMet/Met) reproduces the phenotypic hallmarks in humans with the variant allele. In the mouse, BDNFMet was expressed in brain at normal levels. However, when mouse were exposed to stressful conditions, BDNFMet/Met mice exhibited increased anxiety-related behaviors that were not normalized by the antidepressant and fluoxetine. That suggests that a variant BDNF may play a key role in genetic predispositions to anxiety and depressive disorders [127]. As of 2008, Val66Met is probably the most investigated SNP of the BDNF gene [123,128]. But there are other SNPs in the gene, including C270T, rs7103411, rs2030324, rs2203877, rs2049045, and rs7124442. Recently, it was reported that the BDNFMet polymorphism contributes to abnormalities in memory extinction. This abnormality in extinction learning may be explained by alterations in neuronal morphology, as well as decreased neural activity in the specific brain region, the ventromedial prefrontal cortex [129].

Furthermore, the Val66Met polymorphism has also been widely investigated as a genetic susceptibility risk factor for a large spectrum of neuropsychiatric disorders, in particular those with a neurodevelopmental origin [130-132]. For example, Met carriers (Val/ Met and Met/Met) had a significant BDNF protein level reduction in Amniotic Fluid (AF) comparing to non-carriers (Val/Val), suggesting that AF BDNF levels could be indicative of fetal CNS development [133] and supporting the involvement of this polymorphism in behavioral and functional brain individual differences in adulthood. Since BDNF and its receptor TrkB mRNA increased in the paraventricular nucleus after acoustic challenge and prelimbic BDNF is critical for consolidation of learned fear memories [134], the role of BDNF in startle is suggested. Gatt et al. [135] demonstrated a significant interaction of BDNF with early life stress; BDNF Met carriers exposed to stress early in life have smaller hippocampal and amygdala volumes, heart rate elevations and a decline in working memory. The interaction of BDNF Met-stress in early life also predicted elevated neuroticism and higher depression and anxiety by elevations in body arousal. In contrast, the combination of BDNF Val/Val genotype and early life stress predicted increases in gray matter of the amygdala and associated medial prefrontal cortex, which in turn predicted startle-elicited heart rate variability and higher anxiety. Overall, these findings may aid establishing an evidence base for BDNF and startle research.

\section{Conclusions}

There are studies with human subjects demonstrating the association between a list of candidate genes, including COMT, GLRA1, GlyT2, and 5HTTLPR and startle response. These association studies in humans were at least partially supported by results of animal studies. In addition, the information from the animal studies indicates a list of candidate genes that warrant human studies. This review provides a framework for identifying a biomarker for exaggerated startle response. Despite some issues that remain to be resolved, the startle response and genotyping appear to provide a valuable endophenotype for underlying gene and environment interaction in startle, a hallmark of PTSD.

\section{Conflict of interest}

The authors declare no conflict of interest.

\section{References}

[1] Davis M, Gendelman DS, Tischler MD, Gendelman PM. A primary acoustic startle circuit: lesion and stimulation studies. J Neurosci 1982;2:791-805.

[2] Castellote JM, Kumru H, Queralt A, Valls-Sole J. A startle speeds up the execution of externally guided saccades. Exp Brain Res 2007;177:129-36.

[3] Hoffman HS, Ison JR. Reflex modification in the domain of startle: I. Some empirical findings and their implications for how the nervous system processes sensory input. Psychol Rev 1980;87:175-89.

[4] Cromwell HC, Klein A, Mears RP. Single unit and population responses during inhibitory gating of striatal activity in freely moving rats. Neuroscience 2007; 146:69-85.

[5] Braff DL, Grillon C, Geyer MA. Gating and habituation of the startle reflex in schizophrenic patients. Arch Gen Psychiatry 1992:49:206-15.

[6] Braff DL, Geyer MA, Swerdlow NR. Human studies of prepulse inhibition of startle: normal subjects, patient groups, and pharmacological studies. Psychopharmacology (Berl) 2001;156:234-58.

[7] Swerdlow NR, Weber M, Qu Y, Light GA, Braff DL. Realistic expectations of prepulse inhibition in translational models for schizophrenia research. Psychopharmacology (Berl) 2008;199:331-88. 
[8] Swerdlow NR, Light GA, Cadenhead KS, Sprock J, Hsieh MH, Braff DL. Startle gating deficits in a large cohort of patients with schizophrenia: relationship to medications, symptoms, neurocognition, and level of function. Arch Gen Psychiatry 2006;63:1325-35.

[9] Duncan E, Szilagyi S, Schwartz M, Kunzova A, Negi S, Efferen T, et al. Prepulse inhibition of acoustic startle in subjects with schizophrenia treated with olanzapine or haloperidol. Psychiatry Res 2003;120:1-12.

[10] Groves PM, Thompson RF. Habituation: a dual-process theory. Psychol Rev 1970;77:419-50.

[11] Grillon C, Morgan III CA, Davis M, Southwick SM. Effect of darkness on acoustic startle in Vietnam veterans with PTSD. Am J Psychiatry 1998:155:812-7.

[12] Quednow BB, Schmechtig A, Ettinger U, Petrovsky N, Collier DA, Vollenweider FX, et al. Sensorimotor gating depends on polymorphisms of the serotonin-2A receptor and catechol-0-methyltransferase, but not on neuregulinArg38Gln genotype: a replication study. Biol Psychiatry 2009;66:614-20.

[13] Quednow BB, Kuhn KU, Mossner R, Schwab SG, Schuhmacher A, Maier W, et al. Sensorimotor gating of schizophrenia patients is influenced by 5-HT2A receptor polymorphisms. Biol Psychiatry 2008;64:434-7.

[14] Kang HC, Jeong You S, Jae Chey M, Sam Baik J, Kim JW, Ki CS. Identification of a de novo Lys304Gln mutation in the glycine receptor alpha-1 subunit gene in a Korean infant with hyperekplexia. Mov Disord 2008;23:610-3.

[15] Brauer D, Strobel A. Hensch T, Diers K, Lesch KP, Brocke B. Genetic variation of serotonin receptor function affects prepulse inhibition of the startle. J Neural Transm 2009;116:607-13.

[16] Stark KL, Burt RA, Gogos JA, Karayiorgou M. Analysis of prepulse inhibition in mouse lines overexpressing 22q11.2 orthologues. Int J Neuropsychopharmacol 2009:1-7.

[17] Levin R, Heresco-Levy U, Bachner-Melman R, Israel S, Shalev I, Ebstein RP. Association between arginine vasopressin 1a receptor (AVPR1a) promoter region polymorphisms and prepulse inhibition. Psychoneuroendocrinology 2009;34:901-8.

[18] Lee HF, Tsai CR, Chi CS, Chang TM, Lee HJ. Aromatic L-amino acid decarboxylase deficiency in Taiwan. Eur J Paediatr Neurol 2009;13:135-40.

[19] Roussos P, Giakoumaki SG, Bitsios P. A risk PRODH haplotype affects sensorimotor gating, memory, schizotypy, and anxiety in healthy male subjects. Biol Psychiatry 2009;65:1063-70.

[20] Hirzel K, Muller U, Latal AT, Hulsmann S, Grudzinska J, Seeliger MW, et al Hyperekplexia phenotype of glycine receptor alpha1 subunit mutant mice identifies $\mathrm{Zn}(2+)$ as an essential endogenous modulator of glycinergic neurotransmission. Neuron 2006;52:679-90.

[21] Roussos P, Giakoumaki SG, Rogdaki M, Pavlakis S, Frangou S, Bitsios P. Prepulse inhibition of the startle reflex depends on the catechol Omethyltransferase Val158Met gene polymorphism. Psychol Med 2008;38:1651-8

[22] Roussos P, Giakoumaki SG, Bitsios P. The dopamine D(3) receptor Ser9Gly polymorphism modulates prepulse inhibition of the acoustic startle reflex. Biol Psychiatry 2008;64:235-40.

[23] Pauli P, Conzelmann A, Mucha RF, Weyers P, Baehne CG, Fallgatter AJ, et al. Affect-modulated startle reflex and dopamine D4 receptor gene variation. Psychophysiology 2010;47:25-33.

[24] Ryan SG, Dixon MJ, Nigro MA, Kelts KA, Markand ON, Terry JC, et al. Genetic and radiation hybrid mapping of the hyperekplexia region on chromosome 5q. Am J Hum Genet 1992;51:1334-43.

[25] Brody SA, Geyer MA. Interactions of the mGluR5 gene with breeding and maternal factors on startle and prepulse inhibition in mice. Neurotox Res 2004;6:79-90.

[26] Gregory ML, Guzauskas GF, Edgar TS, Clarkson KB, Srivastava AK, Holden KR. A novel GLRA1 mutation associated with an atypical hyperekplexia phenotype. J Child Neurol 2008;23:1433-8.

[27] Lonsdorf TB, Weike AI, Nikamo P, Schalling M, Hamm AO, Ohman A. Genetic gating of human fear learning and extinction: possible implications for geneenvironment interaction in anxiety disorder. Psychol Sci 2009;20:198-206.

[28] Dulawa SC, Hen R, Scearce-Levie K, Geyer MA. Serotonin1B receptor modulation of startle reactivity, habituation, and prepulse inhibition in wild-type and serotonin1B knockout mice. Psychopharmacology (Berl) 1997; $132: 125-34$

[29] Armbruster D, Moser DA, Strobel A, Hensch T, Kirschbaum C, Lesch KP, et al. Serotonin transporter gene variation and stressful life events impact processing of fear and anxiety. Int $\mathrm{J}$ Neuropsychopharmacol 2009;12:393-401.

[30] Heils A, Teufel A, Petri S, Stober G, Riederer P, Bengel D, et al. Allelic variation of human serotonin transporter gene expression. J Neurochem 1996;66:2621-4

[31] Heils A, Teufel A, Petri S, Seemann M, Bengel D, Balling U, et al. Functional promoter and polyadenylation site mapping of the human serotonin (5-HT) transporter gene. J Neural Transm Gen Sect 1995;102:247-54.

[32] Wendland JR, Martin BJ, Kruse MR, Lesch KP, Murphy DL. Simultaneous genotyping of four functional loci of human SLC6A4, with a reappraisal of 5HTTLPR and rs25531. Mol Psychiatry 2006;11:224-6.

[33] Hariri AR, Mattay VS, Tessitore A, Kolachana B, Fera F, Goldman D, et al Serotonin transporter genetic variation and the response of the human amygdala. Science 2002;297:400-3.

[34] Glatt CE, Freimer NB. Association analysis of candidate genes for neuropsychiatric disease: the perpetual campaign. Trends Genet 2002;18: 307-12.
[35] Lesch KP, Bengel D, Heils A, Sabol SZ, Greenberg BD, Petri S, et al. Association of anxiety-related traits with a polymorphism in the serotonin transporter gene regulatory region. Science 1996;274:1527-31.

[36] Munafo MR, Lingford-Hughes AR, Johnstone EC, Walton RT. Association between the serotonin transporter gene and alcohol consumption in social drinkers. Am J Med Genet B Neuropsychiatr Genet 2005;135B:10-4.

[37] Schinka JA, Busch RM, Robichaux-Keene N. A meta-analysis of the association between the serotonin transporter gene polymorphism (5-HTTLPR) and trait anxiety. Mol Psychiatry 2004;9:197-202.

[38] Sen S, Burmeister M, Ghosh D. Meta-analysis of the association between a serotonin transporter promoter polymorphism (5-HTTLPR) and anxietyrelated personality traits. Am J Med Genet B Neuropsychiatr Genet 2004;127B:85-9.

[39] Heinz A, Braus DF, Smolka MN, Wrase J, Puls I, Hermann D, et al. Amygdalaprefrontal coupling depends on a genetic variation of the serotonin transporter. Nat Neurosci 2005;8:20-1.

[40] Pezawas L, Meyer-Lindenberg A, Drabant EM, Verchinski BA, Munoz KE, Kolachana BS, et al. 5-HTTLPR polymorphism impacts human cingulateamygdala interactions: a genetic susceptibility mechanism for depression. Nat Neurosci 2005;8:828-34.

[41] Brocke B, Armbruster D, Muller J, Hensch T, Jacob CP, Lesch KP, et al. Serotonin transporter gene variation impacts innate fear processing: acoustic startle response and emotional startle. Mol Psychiatry 2006;11:1106-12.

[42] Jacobs N, Kenis G, Peeters F, Derom C, Vlietinck R, van Os J. Stress-related negative affectivity and genetically altered serotonin transporter function: evidence of synergism in shaping risk of depression. Arch Gen Psychiatry 2006;63:989-96.

[43] Eley TC, Sugden K, Corsico A, Gregory AM, Sham P, McGuffin P, et al. Geneenvironment interaction analysis of serotonin system markers with adolescent depression. Mol Psychiatry 2004;9:908-15.

[44] Grabe HJ, Lange M, Wolff B, Volzke H, Lucht M, Freyberger HJ, et al. Mental and physical distress is modulated by a polymorphism in the 5-HT transporter gene interacting with social stressors and chronic disease burden. Mol Psychiatry 2005;10:220-4.

[45] Kendler KS, Kuhn JW, Vittum J, Prescott CA, Riley B. The interaction of stressful life events and a serotonin transporter polymorphism in the prediction of episodes of major depression: a replication. Arch Gen Psychiatry 2005;62:529-35.

[46] Taylor SE, Way BM, Welch WT, Hilmert CJ, Lehman BJ, Eisenberger NI, et al. Early family environment, current adversity, the serotonin transporter promoter polymorphism, and depressive symptomatology. Biol Psychiatry 2006;60:671-6.

[47] Wilhelm K, Mitchell PB, Niven H, Finch A, Wedgwood L, Scimone A, et al. Life events, first depression onset and the serotonin transporter gene. $\mathrm{Br} \mathrm{J}$ Psychiatry 2006;188:210-5

[48] Gogos JA, Santha M, Takacs Z, Beck KD, Luine V, Lucas LR, et al. The gene encoding proline dehydrogenase modulates sensorimotor gating in mice. Nat Genet 1999;21:434-9.

[49] Tunbridge EM, Bannerman DM, Sharp T, Harrison PJ. Catechol-omethyltransferase inhibition improves set-shifting performance and elevates stimulated dopamine release in the rat prefrontal cortex. J Neurosci 2004;24:5331-5.

[50] Lewis CD, Gebber GL, Larsen PD, Barman SM. Long-term correlations in the spike trains of medullary sympathetic neurons. J Neurophysiol 2001:85:1614-22.

[51] Sesack SR, Hawrylak VA, Guido MA, Levey AI. Cellular and subcellular localization of the dopamine transporter in rat cortex. Adv Pharmacol 1998;42:171-4.

[52] Matsumoto M, Weickert CS, Beltaifa S, Kolachana B, Chen J, Hyde TM, et al. Catechol O-methyltransferase (COMT) mRNA expression in the dorsolateral prefrontal cortex of patients with schizophrenia. Neuropsychopharmacology 2003;28:1521-30.

[53] Tunbridge EM, Harrison PJ, Weinberger DR. Catechol-o-methyltransferase cognition and psychosis: Val158Met and beyond. Biol Psychiatry 2006;60:141-51.

[54] Lachman HM, Morrow B, Shprintzen R, Veit S, Parsia SS, Faedda G, et al. Association of codon 108/158 catechol-O-methyltransferase gene polymorphism with the psychiatric manifestations of velo-cardio-facial syndrome. Am J Med Genet 1996;67:468-72.

[55] Chen J, Lipska BK, Halim N, Ma QD, Matsumoto M, Melhem S, et al. Functional analysis of genetic variation in catechol-O-methyltransferase (COMT): effects on mRNA, protein, and enzyme activity in postmortem human brain. Am J Hum Genet 2004;75:807-21.

[56] Blasi G, Mattay VS, Bertolino A, Elvevag B, Callicott JH, Das S, et al. Effect of catechol-O-methyltransferase val158met genotype on attentional control. J Neurosci 2005;25:5038-45.

[57] Egan MF, Goldberg TE, Kolachana BS, Callicott JH, Mazzanti CM, Straub RE, et al. Effect of COMT Val108/158 Met genotype on frontal lobe function and risk for schizophrenia. Proc Natl Acad Sci USA 2001;98: 6917-22.

[58] Winterer G, Egan MF, Kolachana BS, Goldberg TE, Coppola R, Weinberger DR. Prefrontal electrophysiologic "noise" and catechol-O-methyltransferase genotype in schizophrenia. Biol Psychiatry 2006;60:578-84.

[59] Winterer G, Musso F, Vucurevic G, Stoeter P, Konrad A, Seker B, et al. COMT genotype predicts BOLD signal and noise characteristics in prefrontal circuits. Neuroimage 2006;32:1722-32. 
[60] Barnett JH, Jones PB, Robbins TW, Muller U. Effects of the catechol-Omethyltransferase Val158Met polymorphism on executive function: a metaanalysis of the Wisconsin Card Sort Test in schizophrenia and healthy controls. Mol Psychiatry 2007;12:502-9.

[61] Goldberg TE, Egan MF, Gscheidle T, Coppola R, Weickert T, Kolachana BS, et al. Executive subprocesses in working memory: relationship to catechol-Omethyltransferase Val158Met genotype and schizophrenia. Arch Gen Psychiatry 2003;60:889-96.

[62] Malhotra AK, Kestler LJ, Mazzanti C, Bates JA, Goldberg T, Goldman D. A functional polymorphism in the COMT gene and performance on a test of prefrontal cognition. Am J Psychiatry 2002;159:652-4

[63] Nicodemus KK, Kolachana BS, Vakkalanka R, Straub RE, Giegling I, Egan MF, et al. Evidence for statistical epistasis between catechol-O-methyltransferase (COMT) and polymorphisms in RGS4, G72 (DAOA), GRM3, and DISC1: influence on risk of schizophrenia. Hum Genet 2007;120:889-906.

[64] Goldman D, Oroszi G, Ducci F. The genetics of addictions: uncovering the genes. Nat Rev Genet 2005;6:521-32.

[65] Domschke K, Freitag CM, Kuhlenbaumer G, Schirmacher A, Sand P, Nyhuis P, et al. Association of the functional V158M catechol-O-methyl-transferase polymorphism with panic disorder in women. Int J Neuropsychopharmacol 2004;7:183-8

[66] McGrath M, Kawachi I, Ascherio A, Colditz GA, Hunter DJ, De Vivo I. Association between catechol-O-methyltransferase and phobic anxiety. Am J Psychiatry 2004;161:1703-5.

[67] Olsson CA, Anney RJ, Lotfi-Miri M, Byrnes GB, Williamson R, Patton GC. Association between the COMT Val158Met polymorphism and propensity to anxiety in an Australian population-based longitudinal study of adolescent health. Psychiatr Genet 2005;15:109-15.

[68] Olsson CA, Byrnes GB, Anney RJ, Collins V, Hemphill SA, Williamson R, et al. COMT Val(158)Met and 5HTTLPR functional loci interact to predict persistence of anxiety across adolescence: results from the Victorian Adolescent Health Cohort Study. Genes Brain Behav 2007;6:647-52.

[69] Woo JM, Yoon KS, Choi YH, Oh KS, Lee YS, Yu BH. The association between panic disorder and the L/L genotype of catechol-O-methyltransferase. J Psychiatr Res 2004;38:365-70.

[70] Enoch MA, Xu K, Ferro E, Harris CR, Goldman D. Genetic origins of anxiety in women: a role for a functional catechol-O-methyltransferase polymorphism. Psychiatr Genet 2003;13:33-41.

[71] Lang UE, Bajbouj M, Sander T, Gallinat J. Gender-dependent association of the functional catechol-O-methyltransferase Val158Met genotype with sensation seeking personality trait. Neuropsychopharmacology 2007;32:1950-5.

[72] Reuter M, Ott U, Vaitl D, Hennig J. Impaired executive control is associated with a variation in the promoter region of the tryptophan hydroxylase 2 gene. J Cogn Neurosci 2007;19:401-8.

[73] Reuter M, Schmitz A, Corr P, Hennig J. Molecular genetics support Gray's personality theory: the interaction of COMT and DRD2 polymorphisms predicts the behavioural approach system. Int J Neuropsychopharmacol 2006;9:155-66.

[74] Stein MB, Fallin MD, Schork NJ, Gelernter J. COMT polymorphisms and anxiety-related personality traits. Neuropsychopharmacology 2005;30:2092-102.

[75] Pooley EC, Fineberg N, Harrison PJ. The met(158) allele of catechol-Omethyltransferase (COMT) is associated with obsessive-compulsive disorder in men: case-control study and meta-analysis. Mol Psychiatry 2007;12:556-61.

[76] Diatchenko L, Slade GD, Nackley AG, Bhalang K, Sigurdsson A, Belfer I, et al. Genetic basis for individual variations in pain perception and the development of a chronic pain condition. Hum Mol Genet 2005;14:135-43.

[77] Smolka MN, Schumann G, Wrase J, Grusser SM, Flor H, Mann K, et al. Catechol-O-methyltransferase val158met genotype affects processing of emotional stimuli in the amygdala and prefrontal cortex. J Neurosci 2005;25:836-42.

[78] Smolka MN, Buhler M, Schumann G, Klein S, Hu XZ, Moayer M, et al. Genegene effects on central processing of aversive stimuli. Mol Psychiatry 2007;12:307-17.

[79] Drabant EM, Hariri AR, Meyer-Lindenberg A, Munoz KE, Mattay VS, Kolachana $\mathrm{BS}$, et al. Catechol O-methyltransferase val158met genotype and neural mechanisms related to affective arousal and regulation. Arch Gen Psychiatry 2006;63:1396-406.

[80] McNaughton N, Gray JA. Anxiolytic action on the behavioural inhibition system implies multiple types of arousal contribute to anxiety. J Affect Disord 2000;61:161-76.

[81] Tijssen MA, Vergouwe MN, van Dijk JG, Rees M, Frants RR, Brown P. Major and minor form of hereditary hyperekplexia. Mov Disord 2002;17:826-30.

[82] Svenningsson P, Chergui K, Rachleff I, Flajolet M, Zhang X, El Yacoubi M, et al. Alterations in 5-HT1B receptor function by p11 in depression-like states. Science 2006;311:77-80.

[83] Zhang L, Li H, Su TP, Barker JL, Maric D, Fullerton CS, et al. p11 is up-regulated in the forebrain of stressed rats by glucocorticoid acting via two specific glucocorticoid response elements in the p11 promoter. Neuroscience 2008;153:1126-34.

[84] Su TP, Zhang L, Chung MY, Chen YS, Bi YM, Chou YH, et al. Levels of the potential biomarker p11 in peripheral blood cells distinguish patients with PTSD from those with other major psychiatric disorders. J Psychiatr Res 2009;43:1078-85
[85] Santamaria-Kisiel L, Rintala-Dempsey AC, Shaw GS. Calcium-dependent and independent interactions of the $\mathrm{S} 100$ protein family. Biochem J 2006;396:201-14.

[86] Anisman H, Du L, Palkovits M, Faludi G, Kovacs GG, Szontagh-Kishazi P, et al Serotonin receptor subtype and p11 mRNA expression in stress-relevant brain regions of suicide and control subjects. J Psychiatry Neurosci 2008;33:131-41

[87] Zhang L, Su TP, Choi K, Maree W, Li CT, Chung MY, et al. P11 (S100A10) as a potential biomarker of psychiatric patients at risk of suicide. J Psychiatr Res 2010.

[88] Czyrak A, Mackowiak M, Chocyk A, Fijal K, Gadek-Michalska A, Wedzony K. 8OHDPAT-induced disruption of prepulse inhibition in rats is attenuated by prolonged corticosterone treatment. Neuropsychopharmacology 2003;28:1300-10.

[89] Ebstein RP, Israel S, Lerer E, Uzefovsky F, Shalev I, Gritsenko I, et al. Arginine vasopressin and oxytocin modulate human social behavior. Ann NY Acad Sci 2009;1167:87-102.

[90] Armbruster D, Mueller A, Strobel A, Kirschbaum C, Lesch KP, Brocke B. Influence of functional tryptophan hydroxylase 2 gene variation and sex on the startle response in children, young adults, and older adults. Biol Psychol 2010;83:214-21.

[91] Swerdlow NR, Platten A, Hanlon FM, Martinez ZA, Printz MP, Auerbach P. Sensitivity to sensorimotor gating-disruptive effects of apomorphine in two outbred parental rat strains and their $\mathrm{F} 1$ and $\mathrm{N} 2$ progeny. Neuropsychopharmacology 2003;28:226-34.

[92] Swerdlow NR, Shoemaker JM, Auerbach PP, Pitcher L, Goins J, Platten A. Heritable differences in the dopaminergic regulation of sensorimotor gating. II. Temporal, pharmacologic and generational analyses of apomorphine effects on prepulse inhibition. Psychopharmacology (Berl) 2004;174:452-62.

[93] Feifel D, Melendez G, Shilling PD. Reversal of sensorimotor gating deficits in Brattleboro rats by acute administration of clozapine a neurotensin agonist but not haloperidol: a potential predictive model for novel antipsychotic effects. Neuropsychopharmacology 2004;29:731-8.

[94] Buckwalter MS, Testa CM, Noebels JL, Camper SA. Genetic mapping and evaluation of candidate genes for spasmodic, a neurological mouse mutation with abnormal startle response. Genomics 1993;17:279-86.

[95] MacLusky NJ, Cook S, Scrocchi L, Shin J, Kim J, Vaccarino F, et al Neuroendocrine function and response to stress in mice with complete disruption of glucagon-like peptide-1 receptor signaling. Endocrinology 2000;141:752-62.

[96] Becker L, Hartenstein B, Schenkel J, Kuhse J, Betz H, Weiher H. Transient neuromotor phenotype in transgenic spastic mice expressing low levels of glycine receptor beta-subunit: an animal model of startle disease. Eur J Neurosci 2000;12:27-32.

[97] Hong LE, Wonodi I, Stine OC, Mitchell BD, Thaker GK. Evidence of missense mutations on the neuregulin 1 gene affecting function of prepulse inhibition. Biol Psychiatry 2008;63:17-23.

[98] Tijssen MA, Shiang R, van Deutekom J, Boerman RH, Wasmuth JJ, Sandkuijl LA et al. Molecular genetic reevaluation of the Dutch hyperekplexia family. Arch Neurol 1995;52:578-82.

[99] Plappert CF, Pilz PK. The acoustic startle response as an effective model for elucidating the effect of genes on the neural mechanism of behavior in mice. Behav Brain Res 2001;125:183-8.

100] Gomeza J, Ohno K, Hulsmann S, Armsen W, Eulenburg V, Richter DW, et al. Deletion of the mouse glycine transporter 2 results in a hyperekplexia phenotype and postnatal lethality. Neuron 2003;40:797-806.

101] Dai H, Okuda T, Sakurai E, Kuramasu A, Kato M, Jia F, et al. Blockage of histamine $\mathrm{H} 1$ receptor attenuates social isolation-induced disruption of prepulse inhibition: a study in $\mathrm{H} 1$ receptor gene knockout mice. Psychopharmacology (Berl) 2005;183:285-93.

[102] Koch M, Kling C, Becker CM. Increased startle responses in mice carrying mutations of glycine receptor subunit genes. Neuroreport 1996;7:806-8.

[103] Carter RJ, Lione LA, Humby T, Mangiarini L, Mahal A, Bates GP, et al. Characterization of progressive motor deficits in mice transgenic for the human Huntington's disease mutation. J Neurosci 1999;19:3248-57.

[104] Cui C, Booker TK, Allen RS, Grady SR, Whiteaker P, Marks MJ, et al. The beta3 nicotinic receptor subunit: a component of alpha-conotoxin MII-binding nicotinic acetylcholine receptors that modulate dopamine release and related behaviors. J Neurosci 2003;23:11045-53.

[105] Turnock-Jones JJ, Jennings CA, Robbins MJ, Cluderay JE, Cilia J, Reid JL, et al. Increased expression of the NR2A NMDA receptor subunit in the prefrontal cortex of rats reared in isolation. Synapse 2009;63:836-46.

[106] van den Buuse M, Wischhof L, Lee RX, Martin S, Karl T. Neuregulin 1 hypomorphic mutant mice. enhanced baseline locomotor activity but normal psychotropic drug-induced hyperlocomotion and prepulse inhibition regulation. Int J Neuropsychopharmacol 2009;12:1383-93.

[107] Bannon AW, Seda J, Carmouche M, Francis JM, Norman MH, Karbon B, et al. Behavioral characterization of neuropeptide Y knockout mice. Brain Res 2000;868:79-87.

[108] Husum H, Termeer E, Mathe AA, Bolwig TG, Ellenbroek BA. Early maternal deprivation alters hippocampal levels of neuropeptide $Y$ and calcitonin-gene related peptide in adult rats. Neuropharmacology 2002;42:798-806.

[109] Caldwell HK, Stephens SL, Young 3rd WS. Oxytocin as a natural antipsychotic: a study using oxytocin knockout mice. Mol Psychiatry 2009;14:190-6.

[110] Dwivedi Y. Brain-derived neurotrophic factor: role in depression and suicide. Neuropsychiatr Dis Treat 2009;5:433-49. 
[111] Jones KR, Reichardt LF. Molecular cloning of a human gene that is a member of the nerve growth factor family. Proc Natl Acad Sci USA 1990;87:8060-4.

[112] Maisonpierre PC, Le Beau MM, Espinosa 3rd R, Ip NY, Belluscio L, de la Monte $\mathrm{SM}$, et al. Human and rat brain-derived neurotrophic factor and neurotrophin-3: gene structures, distributions, and chromosomal localizations. Genomics 1991;10:558-68.

[113] Matsumoto T, Rauskolb S, Polack M, Klose J, Kolbeck R, Korte M, et al. Biosynthesis and processing of endogenous BDNF: CNS neurons store and secrete BDNF, not pro-BDNF. Nat Neurosci 2008;11:131-3.

[114] Binder DK, Scharfman HE. Brain-derived neurotrophic factor. Growth Factors 2004;22:123-31

[115] Warner-Schmidt JL, Duman RS. Hippocampal neurogenesis: opposing effects of stress and antidepressant treatment. Hippocampus 2006;16:239-49.

[116] Russo-Neustadt AA, Beard RC, Huang YM, Cotman CW. Physical activity and antidepressant treatment potentiate the expression of specific brain-derived neurotrophic factor transcripts in the rat hippocampus. Neuroscience 2000;101:305-12.

[117] Xu Y, Ku B, Tie L, Yao H, Jiang W, Ma X, et al. Curcumin reverses the effects of chronic stress on behavior, the HPA axis, BDNF expression and phosphorylation of CREB. Brain Res 2006;1122:56-64.

[118] Shimizu E, Hashimoto K, Okamura N, Koike K, Komatsu N, Kumakiri C, et al. Alterations of serum levels of brain-derived neurotrophic factor (BDNF) in depressed patients with or without antidepressants. Biol Psychiatry 2003;54:70-5.

[119] Okamoto T, Yoshimura R, Ikenouchi-Sugita A, Hori H, Umene-Nakano W, Inoue $\mathrm{Y}$, et al. Efficacy of electroconvulsive therapy is associated with changing blood levels of homovanillic acid and brain-derived neurotrophic factor (BDNF) in refractory depressed patients: a pilot study. Prog Neuropsychopharmacol Biol Psychiatry 2008;32:1185-90.

[120] Gorgulu Y, Caliyurt O. Rapid antidepressant effects of sleep deprivation therapy correlates with serum BDNF changes in major depression. Brain Res Bull 2009;80:158-62.

[121] Taylor SM. Electroconvulsive therapy, brain-derived neurotrophic factor, and possible neurorestorative benefit of the clinical application of electroconvulsive therapy. J ECT 2008;24:160-5.

[122] Duncan LE, Hutchison KE, Carey G, Craighead WE. Variation in brain-derived neurotrophic factor (BDNF) gene is associated with symptoms of depression. J Affect Disord 2009; 115:215-9.

[123] Egan MF, Kojima M, Callicott JH, Goldberg TE, Kolachana BS, Bertolino A, et al. The BDNF val66met polymorphism affects activity-dependent secretion of BDNF and human memory and hippocampal function. Cell 2003;112: 257-69.
[124] Chen ZY, Patel PD, Sant G, Meng CX, Teng KK, Hempstead BL, et al. Variant brain-derived neurotrophic factor (BDNF) (Met66) alters the intracellular trafficking and activity-dependent secretion of wild-type BDNF in neurosecretory cells and cortical neurons. J Neurosci 2004;24:4401-11.

[125] Montag C, Weber B, Fliessbach K, Elger C, Reuter M. The BDNF Val66Met polymorphism impacts parahippocampal and amygdala volume in healthy humans: incremental support for a genetic risk factor for depression. Psychol Med 2009;39:1831-9.

[126] Matsuo K, Walss-Bass C, Nery FG, Nicoletti MA, Hatch JP, Frey BN, et al Neuronal correlates of brain-derived neurotrophic factor Val66Met polymorphism and morphometric abnormalities in bipolar disorder. Neuropsychopharmacology 2009;34:1904-13.

[127] Chen QY, Chen Q, Feng GY, Wan CL, Lindpaintner K, Wang LJ, et al. Association between the brain-derived neurotrophic factor (BDNF) gene and schizophrenia in the Chinese population. Neurosci Lett 2006;397:285-90.

[128] Bath KG, Lee FS. Variant BDNF (Val66Met) impact on brain structure and function. Cogn Affect Behav Neurosci 2006;6:79-85.

[129] Yu H, Wang Y, Pattwell S, Jing D, Liu T, Zhang Y, et al. Variant BDNF Val66Met polymorphism affects extinction of conditioned aversive memory. J Neurosci 2009;29:4056-64.

[130] Kanazawa T, Glatt SJ, Kia-Keating B, Yoneda H, Tsuang MT. Meta-analysis reveals no association of the Val66Met polymorphism of brain-derived neurotrophic factor with either schizophrenia or bipolar disorder. Psychiatr Genet 2007;17:165-70.

[131] Lanktree M, Squassina A, Krinsky M, Strauss J, Jain U, Macciardi F, et al. Association study of brain-derived neurotrophic factor (BDNF) and LIN-7 homolog (LIN-7) genes with adult attention-deficit/hyperactivity disorder. Am J Med Genet B Neuropsychiatr Genet 2008;147B:945-51.

[132] Chen L, Lawlor DA, Lewis SJ, Yuan W, Abdollahi MR, Timpson NJ, et al. Genetic association study of BDNF in depression: finding from two cohort studies and a meta-analysis. Am J Med Genet B Neuropsychiatr Genet 2008;147B: 814-21.

[133] Cattaneo A, Bocchio-Chiavetto L, Zanardini R, Marchina E, Bellotti D, Milanesi $\mathrm{E}$, et al. BDNF Val66Met polymorphism and protein levels in amniotic fluid. BMC Neurosci 2010;11:16.

[134] Choi SH, Li Y, Parada LF, Sisodia SS. Regulation of hippocampal progenitor cell survival, proliferation and dendritic development by BDNF. Mol Neurodegener 2009;4:52.

[135] Gatt JM, Nemeroff CB, Dobson-Stone C, Paul RH, Bryant RA, Schofield PR. Interactions between BDNF Val66Met polymorphism and early life stress predict brain and arousal pathways to syndromal depression and anxiety. Mol Psychiatry 2009;14:681-95. 